\title{
IN MEMORIAM Ulla C. JOHANSEN (1927-2021)
}

14. veebruaril suri 93-aastaselt Ulla C. Johansen (kusjuures initsiaali C. tähendust ei õnnestunudki mul välja uurida), üks Eesti päritolu Saksa etnoloogia suurkujusid. Ulla Johansen sündis 17. juunil 1927 Tallinnas. Johanseni ema oli baltisakslane ning isa taani päritolu väljapaistev ajaloolane Paul Johansen, kelle raamatut koostöös Heinz von zur Mühleniga, "Sakslane ja mittesakslane keskaegses ja varauusaegses Tallinnas" ("Deutsch und Undeutsch im mittelalterlichen und frühneuzeitlichen Reval”), peetakse üheks parimaks keskaegse Eesti käsitluseks. Perekond rändas 1939. aastal Umsiedlung'i käigus välja Saksamaale, kus Ulla Johansen lõpetas oma koolitee ning omandas ülikoolihariduse. Eestist võttis ta kaasa keeleoskuse, vallates vabalt eesti, vene, saksa ja taani keelt. Elu lõpuni rääkis ta saksa keelt baltisaksa aktsendiga. 1953. aastal kaitses Ulla Johansen Hamburgi Ülikoolis doktoritöö teemal "Jakuutide ornamentika" ("Die Ornamentik der Jakuten"), mis põhines Saksamaa muuseumites talletatud jakuutide materiaalse kultuuri kogude analüüsil. Doktoritöö on saavutanud klassika staatuse ja on ka äärmiselt nõutud raamatukogude poolt. Töö kaitsmisele järgnes uurimistöö Türgis ja 1958. aastast töötamine Hamburgi Etnoloogiamuuseumis (Hamburger Museum für Völkerkunde). 1962. ja 1965. aastal oli ta muuseumi Lõuna- ja Ida-Aasia osakonna juhataja.

Ulla Johansen oli üks esimesi lääne teadlasi, kel avanes võimalus töötada Nõukogude Liidus. Ajal, kui lääne teadlastel oli Nõukogude Liitu sisenemine praktiliselt võimatu, saavutas Ulla Johansen 1960/61. aastal vanemteaduri koha Nõukogude Teaduste Akadeemia Etnograafia ja Antropoloogia Instituudis Moskvas. Tegemist oli juhtiva asutusega nõukogude etnograafias ja seal töötamine tähendas kuulumist nõukogude teaduseliiti. Tänapäeval on väga raske aru saada, kui suletud oli Nõukogude Liit lääne teadlastele. Vaid üksikud said seda külastada ja veel vähem oli neid, kes said seal pikemalt viibida.

1968. aastal kaitses Ulla Johansen Heidelbergi Ülikoolis habilitatsiooniväitekirja "Šamaani riietus tuvalastel. Ettepanekud šamanismiuuringute metoodikasse" ("Die Schamanentracht bei den Tuvanern. Vorschläge zu 
Methodik der Schamanismusforschung"), mis põhines Hamburgi Etnoloogiamuuseumi kogudel. 1973. aastal sai Ulla Johansen Kölni Ülikooli etnoloogiaprofessoriks ja ülikooli etnoloogiainstituudi direktoriks. Tema ametinimetus oli Professorin für Völkerkunde. Siin tuleb teada saksa terminoloogiat: nimelt jaguneb Saksamaal etnoloogia Völkerkunde'ks ja Volkskunde'ks. Viimane seisneb sakslaste etnoloogilises uurimises, samas kui esimene hõlmab kõiki kultuure väljaspool Saksamaad.

1976.-81. aastal tegeles Ulla Johansen välitöödega Türgis kohalike nomaadide juures ning 1970. aastal sai ta isegi Istanbuli Ülikooli külalisprofessoriks. 1976.-80. aastal oli Johansen Deutsche Forschungsgemeinschaft'i (DFG) etnoloogia osakonna esinaine. DFG on Saksamaa suurim teaduslike stipendiumite ja riiklike grantide jagaja, mis sarnaneb Eesti Teadusagentuuriga. Peale selle oli Johansen kümme aastat Saksamaa tähtsaima etnoloogilise teadusajakirja Zeitschrift für Ethnologie (ZfE) peatoimetaja. 1990. aastal läks Ulla Johansen ametlikult pensionile, kuid jätkas siiski töötamist. Sel ajal lagunes Nõukogude Liit ning Ulla Johansenil oli võimalus naasta oma sünnimaale. Järgnesid aastad, mil ta pidas loenguid nii Tartu Ülikoolis kui ka Tallinna Humanitaarinstituudis. Johansen oli üks esimesi lääne etnolooge, kes õpetas Eestis. Mitmed Eesti väljapaistvad etnoloogid käisid tema loengutes ja võib väita, et Ulla Johansenil on suur osa Eesti etnoloogiateaduse suunamisel nõukogude etnograafiast lääneliku etnoloogiani. Johanseni sulest on ka ilmunud seni parim ülevaade eesti etnograafiast nõukogude perioodil. ${ }^{1}$

Hoolimata sellest, et Ulla Johansen on Jakuutias käinud vaid kaks korda ja sedagi alles pärast oma Jakuutia-teemaliste uurimistööde publitseerimist (2008. ja 2012. aastal), jäi ta alatiseks selle piirkonnaga seotuks. 2012. aastal asutati Saksa riikliku stipendiumifondi Deutsche Austauschdiensti (DAAD) juures Ulla Johanseni uurimisstipendium, millega toetatakse Jakuutia teadlaste kuni kuuekuulist viibimist mõnes Saksamaa ülikoolis. Stipendium ja Johanseni edasised Jakuutia-teemalised uurimistööd peegeldavad tema kustumatut armastust selle perifeerse Kaug-Ida regiooni suhtes. 2008. aastal andis Sahha Vabariigi (Jakuutia) parlament Ulla Johansenile aumedali ja teenetekirja. Mõned aastad enne surma annetas Johansen oma Jakuutia-teemalised kogud Sahha Vabariigile, kus neid säilitatakse Jakutskis asuvas Ammosovi-nimelises Föderaalses Kirdeülikoolis. 2018. aastal võttis Ulla Johansen Moskvas president Vladimir Putinilt vastu Vene Geograafiaühingu kuldmedali panuse eest turkoloogiasse. Tseremoonial pidas ta ka lühikese venekeelse kõne ja vestles hiljem Putiniga saksa keeles.

Ulla Johansenit on peetud omaks nii Eestis, Saksamaal kui ka Venemaal. Teda võib vaadelda nii Saksa etnoloogia suurkujuna, kelle panus 
ennekõike šamanismiuuringutesse on jäädvustatud etnoloogiateaduse ajalukku, kui ka meie kodumaise suurnimena maailmateaduses. Tema pärand on suutnud luua sildu eri maade teadlaskondade vahel tänapäeva poliitiliselt lõhestunud maailmas. Olles ise ennekõike Jakuutia-uurija, olen ma tänulik oma kaasmaalasele, et ta pani selle vähetuntud regiooni maailmateaduse kaardile.

Aimar Ventsel 